\title{
Ergenlerin Problemli İnternet Kullanımında Kişilerarası İlişkilerle İlgili Bilişsel Çarpıtmaların ve Sosyal Kaygının Rolü Mehmet ŞAHAN $^{1}$ Bahtiyar ERASLAN ÇAPAN ${ }^{2}$
}

Geliş Tarihi: 2017-08-29

Kabul Tarihi: 2017-10-31

\section{Öz}

$\mathrm{Bu}$ çalışmanın amacı, ergenlerin kişilerarası ilişkilerle ilgili bilişsel çarpıtmaları ve sosyal kaygı düzeyleri ile problemli internet kullanımları arasındaki ilişkiyi incelemektir. Araştırma grubu, Eskişehir'de farklı liselerde öğrenim gören 174'ü kız ve 138'i erkek olmak üzere toplam 312 öğrenciden oluşmaktadır. Katılımcıların yaşları 15 ile 19 arasında değişmektedir ve katılımcıların yaş ortalaması 16,3'tür (Ss: 1.23). Çalışmada veriler Problemli İnternet Kullanım Ölçeği-Ergen, Sosyal Kaygı Ölçeği ve Kişilerarası İlişkilerle İlgili Bilişsel Çarpıtmalar Ölçeği ile toplanmıştır. Veriler korelasyon ve regresyon analizi ile incelenmiştir. Ayrıca ergenlerin problemli internet kullanımı, sosyal kaygı ve kişilerarası ilişkilerle ilgili bilişsel çarpıtmaların cinsiyete göre farklılaşıp farklılaşmadığını belirlemek amacıyla ilişkisiz grup için $t$ testi kullanılmıştır. Bulgular, sosyal kaygı düzeyinin ve kişilerarası ilişkilerle ilgili bilişsel çarpıtmaların problemli internet kullanımıyla pozitif yönde ilişkili olduğunu ve problemli internet kullanımını yordadığını göstermiştir. Değişkenler problemli internet kullanımını yaklaşık olarak \%44 düzeyinde açıklamaktadır. Ayrıca cinsiyet değişkenine göre sosyal kaygı düzeyi farklılık göstermezken, problemli internet kullanımı ve kişilerarası ilişkilerle ilgili bilişsel çarpıtmaları erkeklerin lehine farklılık göstermiştir. Sonuçlar Sosyal Telafi Yaklaşımı ve ilgili alanyazın çerçevesinde tartışılmış ve okul psikolojik danışmanlarına ve araştırmacılara öneriler sunulmuştur.

Anahtar Kelimeler: Problemli internet kullanımı, sosyal kaygı, kişilerarası ilişkilerle ilgili bilişsel çarpitmalar

\footnotetext{
${ }^{1}$ Uzm. Psk. Dan. Milli Eğitim Bakanlığı mehmetsahan.10@gmail.com

2 Doç. Dr. Anadolu Üniversitesi, Eğitim Fakültesi, RPD Anabilim Dalı beraslan@anadolu.edu.tr
} 
The Role of Interpersonal Cognitive Distortions and Social Anxiety in Adolescents'

Problematic Internet Use

Submitted by 2017-08-29

Accepted by 2017-10-31

\begin{abstract}
The purpose of this research is to examine the relationship between problematic internet use and social anxiety and the relationship between interpersonal cognitive distortions among Turkish adolescents. The population of the study was composed of 312 students (174 girls, 138 boys), attending to different high schools in Eskişehir. Ages of the participants ranged between 15 to 19 and the mean was 16.3. Participants completed the Problematic Internet Use Scale- Adolescent, The Social Anxiety Scale for Adolescents and Interpersonal Cognitive Distortions Scale. The research data were analyzed by correlation and regression analysis. Independent sample $\mathrm{t}$ test was used to determine whether problematic internet use and social anxiety and the relationship between interpersonal cognitive distortions of adolescents differentiate according to gender or not. It was found that problematic internet use was correlated positively with social anxiety, and interpersonal cognitive distortions. According to the results, the scores on the problematic internet use scale were predicted positively (44\%) by social anxiety, and interpersonal cognitive distortions. As a result of the research no significant gender difference was found in terms of social anxiety. The research results also showed that adolescents' problematic internet use and interpersonal cognitive distortions significantly differed in terms of gender;male adolescents' problematic internet use and interpersonal cognitive distortions were significantly higher than those of female adolescents. The findings were discussed according to The Social Compensation Theory and related literatures. Based on the interpretations, suggestions were given to school counselors and researchers.
\end{abstract}

Keywords: Problematic internet use, social anxiety, interpersonal cognitive distortions 


\section{Giriș}

Günümüzde çok hızlı biçimde gerçekleşen teknolojik gelişmeler, bireylerin yaşamlarını kolaylaştırırken bir taraftan da farklı sorunların yaşanmasına neden olmaktadır. En önemli teknolojik gelişmelerden olan internet kullanımı; dünyanın pek çok yerine bağlanarak bilgi edinme, haberleşme, alışveriş yapma, oyun oynama gibi günlük hayat faaliyetlerinin kolay bir biçimde gerçekleşmesini sağlamaktadır. Bununla birlikte internetin; ev, okul, iş yeri ve cep telefonu ile bireylerin bulundukları hemen hemen her yerde ulaşılabilir olması, zamanlarının büyük bir kısmını internet başında geçirmelerine ve günlük yaşamlarında sorunlar yaşamalarına neden olabilmektedir.

Aşırı internet kullanımı nedeniyle sosyal, akademik veya iş yaşamında problemler yaşanması durumu olarak tanımlanan "Problemli İnternet Kullanımı" (Yellowlees ve Marks, 2007) hemen her yaşta görülebilirken özellikle 12-18 yaş aralığındaki ergenler için büyük bir tehdit kaynağıdır (Cengizhan, 2005; Şendağ ve Odabaşı, 2007). Türkiye İstatistik Kurumu'nun (TÜİK, 2016) araştırma sonucunda internet kullanım oranının en yüksek olduğu yaş grubunun 16-24 yaşlar arası olduğu belirtilmektedir. Farklı ergen örneklemlerinde yapılan çalışmalarda problemli internet kullanım oranının \% 7 ile \% 20 arasında olduğu (Çam, 2014; Özolgun Kurt, 2014), ergenlerin internette geçirdikleri zamanın ise günde 2 ile 5 saat arasında değiştiği (Durak Batıgün ve Kılıç, 2011; Kelleci, Güler, Sezer ve Gölbaşı, 2009) belirtilmektedir. Bunun yanında erkeklerin problemli internet kullanım düzeylerinin kızlardan daha yüksek olduğunu gösteren araştırmalardan (Ceyhan, 2008; Çelik ve Odac1, 2013; Durak Batıgün ve K1lıç, 2011; Morahan-Martin ve Schumacher, 2003; Özolgun Kurt, 2014; Zorbaz ve Tuzgöl Dost, 2014) farklı olarak kızların problemli internet kullanım düzeylerinin daha yüksek olduğunu gösteren araştırma bulgusu da bulunmaktadır (Doğan, Işıklar ve Eroğlu, 2008). Ancak cinsiyet değişkeni ile problemli internet kullanımı arasında ilişki olmadığını gösteren araştırmalar da mevcuttur (Ceyhan, 2011; Taylan ve Iş1k, 2015). Özetle aileden uzaklaşan ergen, kendine özgü sosyal çevre geliştirme çabası ile interneti daha sık kullanmakta ve zaman konusunda dengeyi oluşturamaması nedeniyle problemli internet kullanıcısı haline gelerek eğitim, aile ve sosyal hayatında sorunlarla karşılaşmaktadır (Ceyhan, 2008).

Ergenlik döneminde yalnızlık isteği, utangaçlık, aile üyeleri ve akranlarla ilgili problemler ergeni, bu sorunlardan uzaklaşabileceğini düşündüğü koşulların var olduğu internete yöneltmektedir (Ögel, 2012). Gelişimsel özellikleri de düşünüldügünnde ergenler, 
sosyal ilişkilerde yüz yüze etkileşime sıcak bakmayarak, internet aracılıyla iletişim kurmayı tercih etmektedirler (Caplan, 2002). Bu durum ergenin, pek çok ihtiyacını karşılayabileceği, onay gördüğü, eğlendiği, daha az çatışma yaşayabileceği, duygu ve düşüncelerinin önemsendiği bir ortam olarak düşündüğü internette, daha çok vakit geçirmesine neden olmaktadır (Çevik, 2016). İnternetin aşırı kullanımı ile birlikte ergenlerde öfke, yalnızlık, utangaçlık gibi duyguların yanı sıra depresyon, kaygı bozukluğu, sosyal beceri eksikliği, alkol ve tütün kullanımı gibi ergenlerin yaşamlarını olumsuz etkileyebilecek alışkanlıklar ortaya çıkmaktadır (Aydın ve Sarı, 2011; Batıün ve Hasta, 2010; Cömert ve Ziyalar, 2012; Siyez ve Baş, 2013).

Alanyazında problemli internet kullanımı ile ilgili araştırmalar artarak devam etmektedir. Problemli internet kullanımının, depresyon, özgüven, yalnızlık, çekingenlik, utangaçlık ve sosyal destek ile ilişkili olduğu görülmektedir (Ceyhan ve Ceyhan, 2014). Problemli internet kullanımının yalnızlık, özgüven ve utangaçlık gibi değişkenlerle ilişkili olması, ergenlerin sosyal ilişki ihtiyaçlarını nasıl giderdikleri sorunu akıllara getirmektedir. Bu noktada ergenlerin günlük hayatta karşılayamadıkları sosyal ilişkileri internet aracılığı ile karşılamaya çalışmaları "Sosyal Telafi Yaklaşımı” ile açıklanmaktadır (Peter, Valkenburg ve Schouten, 2005). Bu yaklaşıma göre gerçek hayatta yüz yüze ilişki kuramayan bireyler, sanal ortamda oluşturdukları gruplarla ait olma ve benliğini ortaya koyma gibi ihtiyaçlarını karşılama çabası içine girmektedirler (Ellison, Steinfield ve Lampe, 2007). Özellikle sosyal kayg1 yaşayan bireyler, internet üzerinden sanal iletişimi yüz yüze iletişime tercih edebilmektedir. Sanal iletişimde birey, olumsuz bulduğu, beğenmediği özelliklerini gizleyebilmekte ya da değiştirebilmekte, ayrıca kendisi ile ilgili özellikleri uydurarak veya abartarak sunabilmektedir (Caplan, 2006). İnternet üzerinden kurulan ilişkilerde, reddedilme ve eleştirilme ihtimalinin az olması (Eldeleklioğlu ve Vural, 2013) nedeniyle sosyal kaygı yaşayan bireyler için internet, kimliklerini gizleyebildiklerinden dolayı daha cazip hale gelmektedir (Caplan, 2006; Morahan-Martin ve Shumacher, 2003). Sanal ortamın sağladığ1 kolaylıklar nedeniyle sosyal kaygı düzeyi yüksek olan bireylerin günlük yaşamda karşılayamadıkları sosyal faydayı internet yoluyla karşılamaya çalıştıkları gözlenmektedir.

Sosyal kaygının görülmeye başladığı yaşın yaklaşık 13- 14 yaş civarı olduğu ve ergenliğin ortalarında sosyal kaygı bozukluğunun doruk noktasına ulaştığı kabul edilmektedir (Akdemir ve Cinemre, 1996; Johnson, Inderbitzen-Nolan ve Anderson, 2006). Sosyal kayg1 bozukluğunun Türk ergenler arasındaki yaygınlık oranının \% 14,4 olduğu bildirilmektedir 
(Bayramkaya, Toros ve Özge, 2005). Bunun yanında kadınların sosyal kaygı düzeylerinin daha yüksek olduğunu gösteren araştırmalardan (Aydın ve Tekinsav-Sütçü, 2007; Gültekin ve Dereboy, 2011; Jose, Ryan, ve Pryor, 2012) farklı olarak, erkeklerin sosyal kaygı düzeylerinin daha yüksek olduğunu gösteren araştırmalar da vardır (Kalkan, 2008; Noyan ve Sertel Berk, 2007). Ancak cinsiyet değişkeni ile sosyal kaygı arasında ilişki olmadığını gösteren araştırmalar da mevcuttur (Atarbay, 2017; Ayberk, 2011; Temizel, 2014; Vatansever-Bulut. 2016). Kişinin yaşadığı sosyal kaygının yüksek olması, sosyal ortamdan uzaklaşarak iletişim kurmasını engellemekte veya zorlaştırmakta ve yalnızlığa neden olabilmektedir. Ayrıca sosyal ortamlardan kaçınılması, sosyal ilişkilerin psikolojik yararının yoksunluğuna yol açmaktadır. Yaşanan bu olumsuzluklardan kaçınmak için ergenlerin sosyalleşme ihtiyaçlarını internet aracılığıyla karşıladıkları bilinmektedir (Canoğulları, 2014; Liu ve Kuo. 2007; Madell ve Muncer 2006; Morahan-Martin ve Schumacher, 2003; Zorbaz ve Tuzgöl Dost, 2014). Bundan dolayı sosyal kaygılı kişilerin problemli internet kullanımına yatkın olduğu söylenebilir.

Sosyal kaygının alanyazında pek çok nedeni olabileceği belirtilmektedir. Bilişsel yaklaşım, sosyal kaygılı kişilerin performanslarına ilişkin çarpıtılmış değerlendirmeleri olduğunu, başkaları tarafindan gözlendiklerine ve kendilerine yönelik olumsuz yorumlar yapıldığına dair inançları olduğunu savunmaktadır (Clark ve Wells, 1995). Bilindiği üzere ergenlik sürecinde bireyler yetişkin düşüncesine özgü bilişsel yetiler kazanmaktadır (Santrock, 2014). Ergenlik döneminde, çevreyle olan ilişkilerde bilgi işleme sürecinin yanlış ya da etkili olmadığı; seçici soyutlama, aşırı genelleme, kişiselleştirme vb. biçimlerde düşüncelerdeki tipik hatalar olarak adlandırılan bilişsel çarpıtmalar meydana gelebilmektedir (Beck, 2001). Bireylerin gelişiminin en hızlı olduğu ergenlik döneminde, önemli sorunlara yol açan bilişsel çarpıtmalar oldukça fazla görülmektedir (Öncü ve Sakarya, 2013). Çünkü ergenlik döneminin getirdiği değişim süreci ve yeniliklere uyum süreci nedeniyle ergenlerin bilişsel çarpıtmalara daha açık olduğu söylenebilir. Alanyazında kadınların bilişsel çarpıtma düzeylerinin erkeklerden daha yüksek olduğunu gösteren araştırma sonucunun (Altıntaş, 2006) yanında erkeklerin bilişsel çarpıtma düzeylerinin daha yüksek olduğunu gösteren araştırmalar da bulunmaktadır (Çivan, 2013; Çoban, 2013; El-Salameh, 2011; Kurtoğlu, 2009). Ancak cinsiyet değişkeni ile bilişsel çarpıtmalar arasında ilişki olmadığını gösteren araştırmalar da mevcuttur (Çivitçi, 2006; Muhtaroğlu, 2016; Stackert ve Bursik, 2003; Şahin ve Sarı, 2010; Turan, 2010). Bilişsel çarpıtmalar, belirli bir ilişki durumuna yönelik olabileceği gibi bütün kişilerarası ilişkileri kapsayacak şekilde de genellenebilmektedir (Hamamcı ve Büyüköztürk, 2003). Kişilerarası ilişkilerle ilgili bilişsel çarpıtmaları olan 
bireylerin karşı tarafın söylediklerini yanlış yorumladıkları (Akın, 2010), ilişkilerde çatışma yaşama eğiliminde oldukları (Hamamcı ve Büyüköztürk, 2003), duygusal olarak dengesiz oldukları (Sava, 2009), sosyal kaygı yaşadıkları (Whisman ve Friedman, 1998), kaygı ve depresyon gibi olumsuz duygular yaşadıkları (Beck, 2001) için bu bireylerin sağlıklı kişilerarası ilişkiler geliştirmede zorlandığı söylenebilir. Sağlıklı kişilerarası ilişkiler geliştiremeyen bireyler sosyal ilişki ihtiyaçlarını internet aracılığıyla sanal ortamı kullanarak giderebilirler. Bu kapsamda sosyal kaygılı bireylerin kişilerarası ilişkilere yönelik bilişsel çarpıtmalara sahip olduğunu söylemek mümkün olabilir. Bundan dolayı kişilerarası ilişkilere yönelik bilişsel çarpıtmalara sahip olan ve sosyal kaygı yaşayan ergenlerin sosyal ilişkilerden uzak durmayı ve sosyal çevreden kendini uzaklaştırmayı tercih ettiği düşünülebilir.

Problemli internet kullanımı bireylerin yaşamlarını pek çok alanda etkilediği için çok fazla sayıda değişken ile ilişkileri incelenmiştir. Alanyazında problemli internet kullanımı ile depresyonun, (Bayraktar, 2001; Huan, Ang ve Chye, 2014; Keser Özcan ve Buzlu, 2005; Şahin, Özdemir, Ünsal, 2013; Young ve Rodgers, 1998), yalnızlığın (Çelik ve Odacı, 2013; Keser Özcan ve Buzlu, 2005; Morahan- Martin ve Schumacher, 2003), anksiyetenin, (Çuhadar, 2012; Huan ve diğ., 2014), olumsuz değerlendirilme korkusunun (Zorbaz ve Tuzgöl Dost, 2014), bilişsel çarpıtmaların (Çelik ve Odacı, 2013; Mai,Hu,Yan,Zhen, Wang ve Zhang, 2012), sosyal kaygının (Liu ve Kuo, 2007; Öztürk, Odabaşığlu, Eraslan, Genç ve Kalyoncu, 2007; Yellowlees ve Marks, 2007; Yen, Ko, Yen, Wu ve Yang, 2007; Yen ve diğ., 2012) ilişkili olduğunu gösteren araştırmalar mevcuttur. Ancak sosyal kaygı ve kişilerarası ilişkilerle ilgili bilişsel çarpıtmaların problemli internet kullanımıyla ilişkisinin birlikte incelendiği bir çalışmaya rastlanmamıştır. Kimlik gelişiminin kritik olduğu ergenlik döneminde, problemli internet kullanımın azaltılması ve önlenmesi adına bu araştırma sonuçlarının, ergenlere yönelik rehberlik ve psikolojik danışma hizmetleri oluşturulmasına katkı sağlayacağı düşünülmektedir.

$\mathrm{Bu}$ noktada bireyin ilerleyen yıllarda psikolojik bozukluklar yaşamasını engellemek için ergenlik döneminde oluşabilecek, kişilerarası ilişkilerle ilgili bilişsel çarpıtmaların ve sosyal kaygının tespit edilip düzeltilmesine yönelik çalışmaların yapılmasında bu araştırma bulgularının katkı sağlayacağı düşünülmektedir. Bundan dolayı bu çalışmanın amacı ergenlerin kişilerarası ilişkilerle ilgili bilişsel çarpıtmaların ve sosyal kaygı düzeyleri ile problemli internet kullanımları arasındaki ilişkilerin tespit edilmesidir. Bu amaçla araştırmada aşağıdaki sorulara cevap aranmıştır: 
1. Ergenlerin sosyal kaygı düzeyleri, kişilerarası ilişkilerle ilgili bilişsel çarpıtmaları ve problemli internet kullanımları cinsiyete göre farklılık göstermekte midir?

2. Ergenlerin kişilerarası ilişkilerle ilgili bilişsel çarpıtma düzeyleri ve sosyal kaygı düzeyleri problemli internet kullanımını yordamakta mıdır?

\section{Yöntem}

Araştırma lise öğrencilerinin problemli internet kullanım düzeylerini belirlemeye yönelik ilişkisel tarama modelinde yapılmıştır. İlişkisel tarama modeli iki ya da daha fazla sayıdaki değişken arasında birlikte değişimin varlığını ve derecesini belirlemeyi amaçlayan araştırma modelidir (Karasar, 2002).

\section{Çalışma Grubu}

Araştırmanın çalışma grubunu 2016-2017 eğitim öğretim yılında Eskişehir ilinde Sağlık Meslek Lisesi, Güzel Sanatlar Lisesi ve Anadolu Lisesinde öğrenim gören 312 öğrenci oluşturmaktadır. Çalışma grubu, araştırmacının ihtiyacı olan verilere en kolay ve en uygun yoldan ulaşabildiği uygun ya da kolay örnekleme yöntemiyle (Gürbüz ve Şahin, 2016) belirlenmiştir. Çalışma grubunda 174 kız (\% 55) ve 138 erkek (\% 45) öğrenci yer almaktadır. Çalışma grubunda yer alan katılımcıların yaşları 15 ile 19 arasında değişmektedir ve katılımcıların yaş ortalaması 16,3'tür (Ss: 1.23).

\section{Veri Toplama Araçları}

Araştırmada veriler Ergenler için Sosyal Kaygı Ölçeği, Kişilerarası İlişkilerle İlgili Bilişsel Çarpıtmalar Ölçeği ve Problemli İnternet Kullanımı-Ergen Ölçeği kullanılarak toplanmıştır.

\section{Ergenler İçin Sosyal Kaygı Ölçeği (ESKÖ)}

Çocuklarda sosyal kaygıyı ölçmek amacıyla LaGreca, Dandes ve Wick (1988) tarafından geliştirilmiş olan ölçek daha sonra LaGreca ve Lopez (1998) tarafindan ergenlere uyarlanmıştır (Akt:Aydın ve Tekinsav-Sütçü, 2007). Ölçeğin Türk kültürüne uyarlama çalışması Aydın ve Tekinsav-Sütçü (2007) tarafından yapılmıştır. Beşli likert tipi cevaplama olanağı veren ölçek toplam 22 maddeden oluşmaktadır. Ölçekten alınan yüksek puan sosyal kaygının yüksek olduğunu işaret etmektedir. Ölçek, olumsuz değerlendirilme korkusu, genel durumlarda sosyal kaçınma ve huzursuzluk duyma ile yeni durumlarda sosyal kaçınma ve 
huzursuzluk duyma olmak üzere üç faktörlü yapıya sahiptir (Aydın ve Tekinsav-Sütçü, 2007). Ölçeğin ergenlere uyarlama çalışması Zorbaz (2013) tarafından yapılmıştır. ESKÖ’nün iç tutarlılığına ilişkin Cronbach alfa katsayısı .91 ve test tekrar test güvenirlik katsayısı .82 olarak bulunmuştur. Doğrulayıcı faktör analizine göre üç boyutlu model olduğu görülmüştür. Ölçekteki maddelerin faktör yükleri .41 ve .79 arasında değişmektedir (Zorbaz, 2013). Bu araştırma kapsamında ise ESKÖ’ye ilişkin Cronbach alfa katsayısı .82 olarak bulunmuştur.

\section{Kişilerarası İlişkilerle İlgili Bilişsel Çarpıtmalar Ölçeği}

Ölçek, Hamamcı ve Büyüköztürk (2003) tarafından bireylerin kişilerarası ilişkilerinde sahip oldukları bilişsel çarpıtmaları değerlendirmek amacıyla geliştirilmiştir. Beşli likert tipi cevaplamaya uygun olan ölçek 19 maddeden oluşmaktadır. Ölçekten alınan yüksek puan, bireyin yakın ilişkilere yönelik bilişsel çarpıtmaları olduğunu göstermektedir. Ölçeğin tümü için iç tutarlılık katsayısı .67 dir. Test-tekrar test katsayısı .74 tür. Temel bileşenler faktör analizi sonucunda ölçeğin yakınlıktan kaçınma, gerçekçi olmayan ilişki beklentisi ve zihin okuma olarak üç faktörlü yapıda olduğu saptanmıştır. Ölçeğin ölçüt geçerliği için, Bilişsel Çarpıtmalar Ölçeği, Otomatik Düşünceler Ölçeği ve Çatışma Eğilim Ölçeği ile korelasyonu incelenmiş ölçeklerle olumlu ve anlamlı ilişki gösterdiği bulunmuştur ( $p<.01)$ (Hamamcı ve Büyüköztürk, 2003). Bu araştırmada Kişilerarası İlişkilerle İlgili Bilişsel Çarpıtmalar Ölçeğine ilişkin Cronbach alfa katsayısı .83 tür.

\section{Problemli İnternet Kullanımı Ölçeği-Ergen (PİKÖ-E)}

Ceyhan, Ceyhan ve Gürcan (2007) tarafından üniversite öğrencilerinin problemli internet kullanım düzeylerini ölçmek için geliştirilmiştir. Ölçek daha sonra Ceyhan ve Ceyhan (2014) tarafından ergenlere uyarlanmış, geçerlik ve güvenirlik çalışmaları yapılmıştır. PİKÖ-E, beşli likert tipi ve 27 maddeden oluşan bir ölçektir. Ölçeğin genel iç tutarlılık katsayısı .93 tür. Ölçeğin açımlayıcı faktör analizi sonucuna göre, internetin olumsuz sonuçları, aşırı kullanım ve sosyal fayda/sosyal rahatlık olmak üzere üç faktörden meydana geldiği toplam varyansın \%49,35'ini açıkladığı görülmektedir. Doğrulayıcı faktör analizi sonuçları da bu üç faktörlü yapıyı doğrulamıştır. Bu araştırma kapsamında PİKÖ’ye ilişkin Cronbach alfa katsayısı .96 dir.

\section{Kişisel bilgi formu}


Öğrencilerin yaş, cinsiyet gibi kişisel bilgilerini belirlemek amacıyla araştırmacı tarafından hazırlanan kişisel bilgi formu kullanılmıştır.

\section{Verilerin Analizi}

Araştırmada ergenlerin problemli internet kullanımlarının, sosyal kaygı düzeylerinin ve kişilerarası ilişkilerle ilgili bilişsel çarpıtma düzeylerinin cinsiyete göre farklılık gösterip göstermediğini belirlemek için ilişkisiz örneklemler için $t$ testi uygulanmıştır. Ayrıca ergenlerin problemli internet kullanımı yordayıcılarını belirlemek amacıyla çoklu regresyon analizi yapılmıştır. Verilerin analizine geçilmeden önce regresyon analizinin ön koşullarından olan normal dağılım, çoklu doğrusal bağlantı ve uç değerler incelenmiştir. Bu çerçevede normal dağılım için basıklık çarpıklık değerlerinin -1.5 ile +1.5 arasında olması (Tabachnick ve Fidell, 2011), Durbin-Watson değerinin 1-3 arasında olmas1 (Akbulut, 2010) ile değişkenler arasındaki ilişkinin .80'den küçük olması (Field, 2005) ölçüt değerler olarak dikkate alınmıştır. Ayrıca çok değişkenli normallik varsayımı Mahalanobis uzaklık değerleri yardımıyla incelenmiştir. Mahalonobis uzaklık değeri için kritik değerin $\left[\mathrm{X}^{2}(2)=13,8\right.$ $p=.001$ )] (Pearson ve Hartley, 1958'den akt: Akbulut, 2010) üstünde bir veriye rastlanmamıştır. Araştırmada, problemli internet kullanımı, sosyal kaygı ve kişilerarası ilişkilerle ilgili bilişsel çarpıtma verileri için çarpıklık katsayılarının -.06 ile 1.37 arasında değiştiği, basıklık katsayılarının -1.31 ile 1.19 arasında değiştiği görülmüş ve bu değerler ile verilerin normal dağıldığına karar verilmiştir. Durbin-Watson değerinin 1.895 olduğundan oto korelasyon sorununun olmadığı görülmüştür. Katılımcıların problemli internet kullanım düzeyleri ile sosyal kaygı ve kişilerarası ilişkilerle ilgili bilişsel çarpıtma düzeyleri arasındaki çoklu doğrusal bağlantı sorununun kontrol edilmesi için değişkenler arasındaki ilişkinin .80’den küçük olması ölçütleri dikkate alınmıştır.

Problemli İnternet Kullanımı Ölçeği’nden alınan puanlar yordanan değişken, sosyal kaygı düzeyi ile kişilerarası ilişkilerle ilgili bilişsel çarpıtma düzeyi ise yordayıcı değişkenler olarak ele alınmıştır. Araştırmada çoklu regresyon analizi ile değişkenler arasındaki ilişkiler incelenmiştir. Araştırmada hata payı .05 olarak kabul edilmiştir. Araştırma kapsamında verilerin analizi “IMB SPSS 21” paket programı ile gerçekleştirilmiştir.

\section{Bulgular}


Araştırmaya katılan ergenlerin cinsiyetlerine göre problemli internet kullanımı (PİK), sosyal kaygı (SK) ve kişilerarası ilişkilerle ilgili bilişsel çarpıtma (KİBÇ) puan ortalamalarının karşılaştırılmasını ilişkin t testi sonuçları Tablo 1'de sunulmuştur.

Tablo 1. Ergenlerin Cinsiyetlerine Göre Problemli Internet Kullanımı, Sosyal Kaygı Düzeyi ve Kişilerarası İlişkilerle İlgili Bilişsel Çarpıtma Düzeyleri, Puan Ortalamalarının Karşılaştırılmasına İlişkin t Testi Sonuçları

\begin{tabular}{llcccccc}
\hline & Cinsiyet & $\mathrm{N}$ & $\bar{x}$ & S. Sapma & S. Hata & t & P \\
\hline S.K. & Erkek & 138 & 46.57 & 12.18 & 1.03 & 1.261 & .208 \\
& Kadın & 174 & 44.85 & 11.90 & .90 & & \\
K.İ. B. Ç. & Erkek & 138 & 50.36 & 13.03 & 1.10 & $3.456^{*}$ & .001 \\
& Kadın & 174 & 55.16 & 11.45 & .86 & & \\
P.I. K. & Erkek & 138 & 86.54 & 29.96 & 2.55 & $3.210^{*}$ & .001 \\
& Kadin & 174 & 75.70 & 29.33 & 2.22 & & \\
\hline
\end{tabular}

$* p<.05$

Tablo 1'deki ergenlerin Sosyal Kaygı Ölçeğinden almış oldukları puanlar incelendiğinde, erkeklerin ortalamalarının $(\bar{x}=46.57)$, kızların ortalamasından $(\bar{x}=44.85)$ yüksek bulunmuştur. İki grubun ortalamalarının karşılaştırılmasına ilişkin $\mathrm{t}$ değeri hesaplanmış ve sonuç iki grubun ortalamaları arasındaki farkın anlamlı olmadığını göstermektedir $(t: 1.261, p>0.05)$. Ergenlerin Kişilerarası İlişkilerle ilgili Bilişsel Çarpıtma Ölçeği'nden almış oldukları puanlar incelendiğinde kızların ortalamasının $(\bar{x}=55.16)$ erkeklerin ortalamasından ( $\bar{x}=50.36)$ yüksek bulunmuştur. İki grubun ortalamalarının karşılaştırılmasına ilişkin $\mathrm{t}$ değeri hesaplanmış ve sonuç iki grubun ortalamaları arasında anlamlı bir fark olduğunu göstermektedir ( $t: 3,456, p<.05)$. Bu sonuç erkeklerin kişilerarası ilişkilerle ilgili bilişsel çarpıtma düzeylerinin daha yüksek olduğunu göstermektedir. Ergenlerin Problemli İnternet Kullanımı Ölçeği’nden almış oldukları puanlar incelendiğinde, erkeklerin ortalaması $(\bar{x}=86.54)$ kızların ortalamasından $(\bar{x}=75.70)$ yüksek bulunmuştur. İki grubun ortalamalarının karşılaştırılmasına ilişkin $t$ değeri hesaplanmış sonuç iki grubun ortalamaları arasında anlamlı bir fark olduğunu göstermektedir $(t: 3,210, p<.05)$. Bu sonuç erkeklerin problemli internet kullanım düzeylerinin kızlara oranla daha yüksek olduğunu göstermektedir.

Ergenlerin kişilerarası ilişkilerle ilgili bilişsel çarpıtma düzeyleri ve sosyal kaygı düzeylerinin problemli internet kullanımına yönelik ilişkilerini incelemek için yapılan korelasyon analizi sonuçları ve betimsel istatistikler Tablo 2'de sunulmuştur 
Tablo 2. Değişkenler Arası Pearson Momentler Çarpımı Korelasyon Katsayıları ve Betimleyici Istatistikler

\begin{tabular}{llll}
\hline Değişkenler & 1 & 2 & 3 \\
\hline P.İ.K. & - & & \\
S. K. & $.661^{*}$ & - & \\
K.İ. B. Ç. & $.222^{*}$ & $.451^{*}$ & - \\
$\bar{x}$ & 80.5 & 45.6 & 53.0 \\
S. Sapma & 30.0 & 12.0 & 12.3 \\
\hline
\end{tabular}

$* p<.05$

Yordayıcı değişkenler ile bağımlı değişken arasındaki ikili korelasyon katsayıları Tablo 2'de incelendiğinde, sosyal kaygı ile problemli internet kullanımı arasında pozitif yönde, yüksek düzeyde ve anlamlı bir ilişkinin ( $r=0.66)$ olduğu görülmektedir. Kişilerarası ilişkilerle ilgili bilişsel çarpıtma ve problemli internet kullanımı arasında ise pozitif yönde, düşük düzeyde ve anlamlı bir ilişkinin $(r=0,22)$ olduğu görülmektedir. Ayrıca sosyal kaygı ile kişilerarası ilişkilerle ilgili bilişsel çarpıtma arasında ise pozitif yönde, orta düzeyde ve anlamlı bir ilişkinin $(r=0,45)$ olduğu görülmektedir.

Tablo 3'te ise katılımcıların problemli internet kullanımının yordayıcıları olarak, sosyal kaygı ve kişilerarası ilişkilerle ilgili bilişsel çarpıtma düzeylerine ilişkin çoklu regresyon analizi sonuçlarına yer verilmiştir.

Tablo 3. Problemli Internet Kullanımının Yordanmasına İlişkin Çoklu Regresyon Analizi Sonuçları

\begin{tabular}{llllllll}
\hline Değişken & B & S. Hata & $\beta$ & T & P & İkili r & K1sm1 r \\
\hline Sabit & 12.591 & 6.205 & - & 2.029 & .366 & & .644 \\
S. K. & 1.755 & .119 & .703 & 14.792 & .000 & .661 & .02 \\
K.İ. B. Ç. & -.229 & .115 & -.95 & -1.988 & .029 & .222 & -112 \\
\hline R=0.666 & & $R^{2}=0.443$ & & & & \\
$\mathrm{~F}(2.309)=123.127$ & $\mathrm{p}=.000$ & & & & \\
\hline
\end{tabular}

Yordayıcı değişkenler ile bağımlı değişken arasındaki ikili ve kısmı korelasyonlar Tablo 3'te incelendiğinde, sosyal kaygı ile problemli internet kullanımı arasında pozitif ve yüksek düzeyde bir ilişkinin ( $r=.66$ ) olduğu, ayrıca diğer değişken kontrol edildiğinde iki değişken arasındaki korelasyonun $r=.64$ olarak hesaplandığı görülmektedir. Kişilerarası ilişkilerle ilgili bilişsel çarpıtma ile problemli internet kullanımı arasında pozitif ve düşük düzeyde bir ilişkinin ( $r=.22)$ olduğu, ancak sosyal kaygı değişkeni kontrol edildiğinde ise iki değişken arasında negatif ve düşük düzeyde bir ilişkinin ( $r=.11)$ olduğu görülmektedir. 
Sosyal kaygı ve kişilerarası ilişkilerle ilgili bilişsel çarpıtma değişkenleri birlikte, ergenlerin problemi internet kullanımı ile yüksek düzeyde ve anlamlı bir ilişki vermektedir $\left(R=0.666, R^{2}=.443, p<.05\right)$. Sosyal kaygı ve kişilerarası ilişkilerle ilgili bilişsel çarpıttma değişkenleri birlikte ergenlerin problemi internet kullanımı toplam varyansın yaklaşık \% 44'ünü açıklamaktadır.

Standardize edilmiş regresyon katsayısına $(\beta)$ göre, yordayıcı değişkenlerin ergenlerin problemli internet kullanımı üzerindeki göreli önem sırası; sosyal kayg1 ve kişilerarası ilişkilerle ilgili bilişsel çarpıtmadır. Regresyon katsayılarının anlamlılığına ilişkin t testi sonuçları incelendiğinde ise her iki değişkenin de ergenlerin problemi internet kullanımı üzerinde önemli bir yordayıcı olduğu görülmektedir.

\section{Tartışma}

$\mathrm{Bu}$ çalışmada ergenlerin sosyal kaygı düzeyleri ve kişilerarası ilişkilerle ilgili bilişsel çarpıtma düzeyleri ile problemli internet kullanımları arasındaki ilişki araştırılmıştır. Bu kapsamda ilk olarak ergenlerin sosyal kaygı düzeylerinin, kişilerarası ilişkilerle ilgili bilişsel çarpıtma düzeylerinin ve problemli internet kullanımının cinsiyete göre farklılık gösterip göstermediği incelenmiştir. Araştırma bulguları, cinsiyet göre ergenlerin sosyal kaygı düzeyleri arasında fark olmadığı ancak kişilerarası ilişkilerle ilgili bilişsel çarpıtma düzeyleri ve problemli internet kullanımları arasında erkekler lehine anlamlı fark olduğu yönündedir. Alanyazında cinsiyet ile sosyal kaygı arasındaki ilişkiye dair araştırma sonuçları incelendiğinde; araştırmanın bulgularına paralel olarak sosyal kaygının cinsiyete göre farklılaşmadığını ortaya koyan araştırmalar da bulunmaktadır (Atarbay, 2017; Ayberk, 2011; Temizel, 2014; Vatansever-Bulut, 2016). Bunun yanında kadınların sosyal kaygı düzeylerinin daha yüksek olduğunu gösteren araştırmalar da (Aydın ve Tekinsav-Sütçü, 2007; Gültekin ve Dereboy, 2011; Jose ve diğ., 2012) görülmektedir. Erkekler ve kadınların sosyal kaygı düzeylerinin farklılaşmamasının nedeni, ergenlik dönemi gelişimsel özellikleri düşünüldüğünde, değerlendirme kaygısını her iki cinsiyetin de benzer biçimlerde yaşaması ile açıklanabilir. Cinsiyet fark etmeksizin ergenlik dönemindeki bireylerin çevre ile iletişim kurarken ya da akran grubundan onay beklerken yaşadıkları sosyal kaygının farklı olmadığı düşünülebilir.

Araştırmanın bir diğer bulgusu ise erkek ergenlerin kişilerarası ilişkilerle ilgili bilişsel çarpıtma düzeylerinin kızlara göre anlamlı olarak daha yüksek olduğudur. Alanyazında araştırma bulgularına paralellik gösteren araştırmalar mevcuttur (Çivan, 2013; Çoban, 2013; 
Kurtoğlu, 2009). Erözkan'ın (2005) yaptığı çalışmada, erkeklerin kişilerarası duyarlılığının kızlardan yüksek olduğu, bu durum erkeklerin başkalarının kendileri hakkındaki duygu ve düşüncelerine daha fazla önem vererek onların istediği şekilde davranmaya eğimli olduğu şeklinde açıklanmıştır. Kültürel yaşantımıza bakıldığında ataerkil bir toplum olarak erkeklerden beklentilerin daha fazla olması, erkeklerin daha fazla bilişsel çarpıtmaya sahip olmasının bir nedeni olarak düşünülebilir. Araştırma grubunda yer alan erkek öğrencilerin toplumun kendilerinden yapmamalarını bekledikleri davranışlar konusunda daha fazla bilişsel çarpıtmaya sahip oldukları düşünülebilir. Ataerkil toplumlardaki erkeklerin cinsiyet rollerine ilişkin daha mükemmeliyetçi bir yaklaşımın olması ve mükemmeliyetçiliğin erkekler tarafından daha fazla sergilendiğini gösteren araştırma sonuçları da (Pirinççi, 2009; Tuncer ve Voltan-Acar, 2006) bu çalışmanın bulgularını destekler niteliktedir.

Bir diğer araştırma bulgusu ise erkek ergenlerin problemli internet kullanımlarının kızlara oranla anlamlı biçimde yüksek olduğudur. Araştırma bulguları alanyazındaki diğer araştırmalarla tutarlılık göstermektedir (Ceyhan, 2008; Çelik ve Odacı, 2013; Durak Batıgün ve K1lıç, 2011; Morahan-Martin ve Schumacher, 2003; Özolgun Kurt, 2014; Zorbaz ve Tuzgöl Dost, 2014). Erkek ergenlerin problemli internet kullanımlarının anlamlı olarak yüksek olmasının nedenleri düşünüldüğünde özellikle online oyunlar gibi internet içeriklerinin erkeklere daha fazla hitap etmesi olabilir (Griffiths, 2008). Ayrıca internet kafeler ve oyun salonları gibi kontrolsüz olarak internete erişim imkânlarının erkekler tarafından daha yoğun kullanılması da erkek ergenlerin problemli internet kullanımlarının yüksek olmasının bir diğer nedeni olabilir.

Araştırmanın diğer sorusunda ise, ergenlerin sosyal kaygı düzeyinin ve kişilerarası ilişkilerle ilgili bilişsel çarpıtmaların problemli internet kullanımını yordayıp yordamadığı incelenmiştir. Bulgulara göre ergenlerin problemli internet kullanımının en önemli yordayıcısının sosyal kaygı olduğu görülmüştür. Aynı zamanda problemli internet kullanımını kişilerarası ilişkilerle ilgili bilişsel çarpıtmaların da önemli bir biçimde yordadığı ortaya çıkmıştır.

Alanyazında sosyal kaygı ile internet kullanımı arasındaki ilişkinin incelendiği araştırmalarda, sosyal kaygı düzeyi yüksek olan bireylerde problemli internet kullanımı ve internet bağımlılı̆̆ı oranlarının da yüksek olduğu görülmektedir. (Canoğulları, 2014; Caplan, 2006; Çuhadar, 2012; Kalecik, 2016; Madell ve Muncer, 2006; Tunalığlu, 2013; Young \& Lo, 2012). Araştırma bulguları alanyazındaki sonuçları destekler niteliktedir. Akran 
ilişkilerinin önemli olduğu ergenlik döneminde sosyal kaygılı ergenler, yüz yüze iletişim kurmaktan kaçındıkları için gerçek yaşamda kuramadıkları sosyal ilişkileri internet aracılığıyla kurabilmektedirler. Ergenler, internette tanımadığı kişilerle herhangi bir risk almadan iletişime geçebilmekte, kendini herhangi bir kısıtlama olmadan ifade edebilmekte ve olduğundan farklı kimlikler altında, herhangi bir reddedilme endişesi taşımadan iletişim kurabilmektedirler. Yüz yüze iletişim kurmaktan kaçınan ve sanal ortamda sosyalleşmeyi tercih eden ergenler, sosyal paylaşım siteleri yoluyla daha kolay arkadaş edinebilmektedirler (Eraslan Çapan ve Sarıçalı, 2016). Böylece sosyal paylaşım sitelerinde kurulan arkadaşlıkları sürdürme yoluyla sosyal yaşamlarını paylaşma, gruba aidiyetlik, benliğini ortaya koyma, onaylanma, beğenilme gibi ihtiyaçlarını karşılamaktadırlar (Eraslan-Capan, 2015; Muslu ve Bolışık, 2009). Sosyal telafi yaklaşımına göre içe dönük ve soysal kaygı yaşayan bireyler sosyal ilişki ihtiyacını internet ortamında kurdukları ilişkilerle giderme yoluna gitmektedirler. Çünkü bu bireyler internet ortamının özelliklerinden dolayı kendilerini daha kolay ifade edebilmektedirler (McKenna, ve Bargh, 2000; Peter ve diğ., 2005). Sosyal telafi kuramına göre sosyal ilişki kurmakta zorluk çeken bu bireyler gerçek yaşamdaki sosyal ilişkiler yerine sanal iletişimi tercih ettikleri için internete bağımlı hale gelmekte (McKenna, Green ve Gleason, 2002), böylece problemli internet kullanıcısı olmaktadırlar.

Araştırmadan elde edilen diğer bulgu, ergenlerin kişilerarası ilişkilerle ilgili bilişsel çarpıtmalarının onların problemli internet kullanımlarının yordayıcısı olduğudur. Araştırma bulguları alanyazındaki sonuçları destekler niteliktedir. Bilişsel çarpıtmaları olan bireyler problemli internet kullanımı göstermektedirler (Çelik ve Odacı, 2013; Mai ve diğ.,2012). Kişilerarası ilişkilerle ilgili bilişsel çarpıtmalar, kişilerin sosyal ilişkilerinde işlevsel olmayan duygu ve davranışların meydana gelmesinde önemli bir faktördür (Akın, 2010). Kişilerarası ilişkilerle ilgili bilişsel çarpıtmalara sahip bireyler, diğerlerinin söylediklerini yanlış yorumladıkları (Akın, 2010), çatışma yaşamaya eğilimli oldukları (Hamamcı ve Büyüköztürk, 2003), öfke, saldırganlık ve zorbalık gösterdikleri (Şahin ve Sarı, 2010; Uğur ve Murat, 2014) yönündeki bulgular bu bireylerin sağlıklı sosyal ilişkiler geliştirmede zorlandığını göstermektedir. Bireylerin kendileri ve yaşadığı dünya ile ilgili olumsuz düşünceleri nedeniyle sağlıklı ilişki kuramamaları, kendilerini istedikleri gibi gösterme imkânı olan internete yönlendirmekte ve sosyalleşme ihtiyaçlarını sanal ortamda karşılamaya çalışmaktadırlar. Bireyler internet aracılığıyla kurdukları ilişkilerde kendileri ile ilgili bilgileri sınırlayabilmekte ve kendilerini istedikleri biçimde tanıtabilmektedirler. Kişilerarası ilişkilerde bilişsel çarpıtmaları olan kişiler, internet ortamında oluşturdukları ideal 
benlikleriyle kurdukları ilişkilerinde kendilerini daha rahat hissetmekte, değerli, sevilen veya başarılı birey olarak inanmaktadırlar. Bu kişilerin gerçek yaşamda alamadıkları değerlilik ve olumlu tepkileri internet ortamındaki sosyal ilişkilerden almaları (Davis 2001) internette daha çok zaman geçirmelerine neden olmaktadır (Karakoç ve Taydaş, 2013). Sonuç olarak kişilerarası ilişkilerle ilgili bilişsel çarpıtmaları bulunan ergenlerin günlük yaşamda gerçek sosyal ilişkiler yerine internet ortamında gerçekleşen ilişkileri tercih ettikleri, böylece internet ortamında daha fazla zaman geçirdikleri söylenebilir.

\section{Sonuç ve Öneriler}

$\mathrm{Bu}$ çalışma, ülkemizde ergenlerin sosyal kaygı düzeyleri ve kişilerarası ilişkilerle ilgili bilişsel çarpıtmaları ile problemli internet kullanımları ilişkisinin ayrıntılı araştırıldığı bir çalışmadır. $\mathrm{Bu}$ çalışma bulguları, ergenlerin sosyal kaygı ve kişilerarası ilişkilerle ilgili bilişsel çarpıtma düzeyleri ile problemli internet kullanımları arasında pozitif yönde ilişki olduğunu ve ergenlerin sosyal ilişki ihtiyacını gerçek yaşam yerine sanal bir ortam olan internet aracılığıyla telafi ettiklerini göstermektedir. Çalışma sonuçları, ülkemizde "Sosyal Telafi Yaklaşımı"nı test etmeye yönelik çalışmalardan biridir. Çalışma bulgularının, ergenler arasında sosyal kaygı yaşayan ve kişilerarası ilişkilerle ilgili bilişsel çarpıtmaları olan problemli internet kullanan risk gruplarının belirlenmesi, önlenmesi ve tedavisi aşamalarında psikolojik yardım hizmeti veren çalışanlara ve araştırmacılara yol göstereceği düşünülmektedir.

Ergenin bilişsel gelişimin kritik döneminde olumsuz yaşantılarla karşılaşması bu dönemde bilişsel çarpıtmaların ergenin düşünce yapısına daha fazla yerleşmesi ihtimalini ortaya çıkarmaktadır (Öncü ve Sakarya, 2013). Bu bağlamda, bilişsel çarpıtmaların ve sosyal kaygının ergenlerin bilişsel gelişimleri ile birlikte sosyal ilişkilerini de etkileyeceği düşünülebilir. Bunun sonucunda kendini daha güvenli hissettiği bir ortam olan internette geçirilen zamanın artabileceği ve ergenlerin problemli internet kullanıcısı haline gelebileceği akıllara gelmektedir. Ayrıca sosyal kaygı; ciddi düzeyde yeti kaybına yol açması, sosyal, akademik ve psikolojik zorluklara zemin hazırlaması, ergenlik yıllarında başlayıp hızla kronikleşmesi göz önüne alındığında tedavi edilmemesi durumunda birey ve toplum için önemli kayıplara yol açmaktadır (Segool ve Carlson, 2008). Bu noktada ergenlik döneminde oluşabilecek bilişsel çarpıtmaların tespit edilmesi bunların düzeltilmesi önemlidir. Okullarda bulunan rehberlik ve psikolojik danışma servislerinin sosyal kaygı yaşayan ve kişilerarası ilişkilerle ilgili bilişsel çarpıtmaları olan ergenleri tespit ederek bireysel ve grupla psikolojik 
danışma faaliyetleri yürütmesi bu ergenleri birer problemli internet kullanıcısı haline gelmesini önleyebilir. Ayrıca yapılacak olan psiko-eğitim programları ile ergenlerin sosyal becerilerini geliştirmeye yönelik faaliyetler yürütülebilir. Okullarda aile eğitim programları ve internet kullanımına yönelik seminer çalışmaları gerçekleştirilebilir.

Çalışmanın alana katkıları yanında bazı sınırlılıkları vardır. Bu çalışmanın, araştırma grubu Eskişehir'de üç farklı lisede öğrenim gören öğrencilerden seçilen örneklemle sınırlı olduğundan, daha kapsamlı örneklemlerle desteklenmeye ihtiyaç vardır. Değişkenler arasında etkili olabilecek diğer gizil değişkenlerin ya da aracı değişkenlerin araştırılarak sosyal kaygı ve kişilerarası ilişkilerle ilgili bilişsel çarpıtmanın, problemli internet kullanımını ne derece yordadığını daha net belirlemek adına, bundan sonra yapılacak olan çalışmalar için önerilebilir. Ayrıca, problemli internet kullanımını daha iyi anlayabilmek adına boylamsal araştırmalara da ihtiyaç duyulmaktadır. Çalışmadaki veri toplama araçları, öz-bildirimsel ölçme araçları olduğu için katılımcıların verdikleri cevaplarla sınırlıdır. Bu nedenle ortaya çıkan sınırlılıkları azaltmak ve daha derinlemesine bilgiler elde etmek için nitel veri toplama tekniklerinin kullanıldığı araştırma desenlerinin bundan sonraki çalışmalarda kullanılmasının yararlı olacağı düşünülmektedir. 


\section{KAYNAKÇA}

Akbulut, Y. (2010). Sosyal bilimlerde SPSS uygulamalarl. İstanbul: İdeal Kültür Yayıncıllk.

Akdemir, A. ve Cinemre, B. (1996). Sosyal fobi: epidemiyoloji, eşlik eden hastalıklar, klinik gidiş, prognoz, 3P Dergisi, 4(1), 11-17.

Akın, A. (2010). Öz duyarlık ve ilişkilerle ilgili bilişsel çarpıtmalar. Hacettepe Üniversitesi Eğitim Fakültesi Dergisi, 39,01-09.

Atarbay S. (2017). Farklı bölümlerde öğrenim gören üniversite öğrencilerinin sosyal kaygı düzeylerinin psikolojik dayanıklılıklarına etkisi. (Yayınlanmamış yüksek lisans tezi). İstanbul Üniversitesi, İstanbul.

Altıntaş, G. (2006). Liseli ergenlerin kişilerarası iletişim becerileri ile akılcı olmayan inançları arasındaki ilişkinin bazı değişkenler açısından incelenmesi. (Yayınlanmamış yüksek lisans tezi). Gazi Üniversitesi, Ankara.

Ayberk, A. (2011). Üniversite ögrencilerinin bağlanma stilleri ve sosyal kaygı düzeylerinin bazı değişkenlere göre incelenmesi. (Yayımlanmamış yüksek lisans tezi). Muğla Üniversitesi, Muğla.

Aydın, B. and Sarı, S.V. (2011). Internet addiction among adolescents: The role of selfesteem. Procedia Social and Behavioral Sciences, 15, 3500-3505. doi:10.1016/j.sbspro.2011.04.325

Aydın, A., ve Tekinsav-Sütçü, S. (2007). Ergenler için sosyal kaygı ölçeğinin (ESKÖ) geçerlik ve güvenirliğinin incelenmesi. Çocuk ve Gençlik Ruh Sağlı̆̆ı Dergisi, 14(2), 79-89.

Batıgün, AD. ve Hasta, D. (2010) İnternet bağımlılığı: Yalnızlık ve kişilerarası ilişki tarzları açısından bir değerlendirme. Anadolu Psikiyatri Dergisi, 11,213-219.

Bayraktar, F. (2001). Internet kullanımının ergen gelişimindeki rolü. (Yayınlanmamış yüksek lisans tezi). Ege Üniversitesi, İzmir.

Bayramkaya, E., Toros, F., ve Özge, C., (2005). Ergenlerde sosyal fobi ile depresyon, öz kavram ve sigara alışkanlığı arasındaki ilişki. Klinik Psikofarmakoloji Bülteni, 15(4),165-173.

Beck, J.S. (2001). Bilişsel terapi:Temel ilkeler ve ötesi. (Çev: N.H Şahin). Ankara : Türk Psikologlar Derneği Yayınları.

Canoğulları, Ö. (2014). Internet bağımlılık düzeyleri farklı ergenlerin cinsiyetlerine göre psikolojik ihtiyaçları, sosyal kayglları ve anne baba tutum algılarının incelenmesi. (Yayınlanmamış yüksek lisans tezi). Çukurova Üniversitesi, Adana. 
Caplan, S. E.(2002). Problematic internet use and psychosocial well-being: development of a theory-based cognitive-behavioral measurement instrument. Computers in Human Behavior, 18(5), 553-75. doi.org/10.1016/S0747-5632(02)00004-3

Caplan, S. E. (2006). Relations among loneliness, social anxiety, and problematic internet use. CyberPsychology \& Behavior, 10(2), 234-242. doi.org/10.1089/cpb.2006.9963

Cengizhan, C.(2005). Öğrencilerin bilgisayar ve internet kullanımında yeni bir boyut: Bağımlılık. M. ̈̈. Atatürk Ĕ̌gitim Fakültesi Eğitim Bilimleri Dergisi, 22, 83-98

Ceyhan, E. (2008). Ergen ruh sağlığı açısından bir risk faktörü: İnternet bağımlılı̆̆ı. Çocuk ve Gençlik Ruh Să̆lı̆̆ı Dergisi, 15(2), 109-116.

Ceyhan, A. A. (2011). Ergenlerin problemli internet kullanım düzeylerinin yordayıcıları. Çocuk ve Gençlik Ruh Să̆lı̆̆ Dergisi, 18(2), 85-94.

Ceyhan, A. A., ve Ceyhan, E. (2014). Problemli internet kullanım ölçeğinin ergenlerde geçerlik ve güvenilirlik çalışması. Bă̆ımlılık Dergisi, 15(2), 56-64.

Ceyhan, E., Ceyhan, A.A. ve Gürcan, A. (2007). Problemli internet kullanımı ölçeğinin geçerlik ve güvenirlik çalışmaları. Kuram ve Uygulamada Eğitim Bilimleri Dergisi, 7 (1), 387-416.

Clark, D.M., and Wells, A., (1995). A cognitive model of social phobia. İçinde R. G. Heimberg,M. R. Liebowitz, D. A. Hope,\& F. R. Schneier (Eds.), Social phobia: diagnosis, assessment, and treatment (s. 69-93). New York: Guilford Press.

Cömert, I. T. and Ziyalar, N. (2012). The association between internet addiction and substance use among 18-28-year-old university students in Istanbul. Psychology Research, 2(10), 615626.

Çam H. H. (2014). Adölesanlarda internet bă̆ımlılı̆̆ı prevalansı ile psikopatolojik semptomlar ve obezite arasındaki ilişkinin incelenmesi. (Yayınlanmamış doktora tezi). Cumhuriyet Üniversitesi. Sivas.

Çelik, Ç.B. and Odacı, H. (2013). The relationship between problematic internet use and interpersonal cognitive distortions and life satisfaction in university students. Children and Youth Services Review, 35(3), 505-508. doi.org/10.1016/j.childyouth.2013.01.001

Çevik, Ç. (2016). Internet kullanım süresinin ergenler üzerindeki psikolojik etkileri. (Yayınlanmamış yüksek lisans tezi). Beykent Üniversitesi, Ankara.

Çivan, İ. (2013). Üniversite öğrencilerinin kişilerarası ilişkilerle ilgili bilişsel çarpıtmaları ve başkalarını bağışlama davranışlarının incelenmesi. (Yayınlanmamış yüksek lisans tezi). Gazi Üniversitesi, Ankara. 
Çoban, E. A. (2013). Geç ergenlerin ilişkilerle ilgili bilişsel çarpıtmaları ve stresle baş etme stratejileri. Avrasya Ĕ̈itim Araştırmaları Dergisi. 51, 65-84.

Çuhadar, C. (2012) Exploration of problematic internet use and social interaction anxiety among Turkish pre-service teachers. Computers\&Education, 59(2), 173-181. doi.org/10.1016/j.compedu.2011.12.029

Davis, R.A. (2001). A cognitive-behavioral model of pathological internet use. Computers in Human Behavior, 17(2), 187-195. doi.org/10.1016/S0747-5632(00)00041-8

Doğan, H., Işıklar, A. ve Eroğlu, E. (2008). Ergenlerin problemli internet kullanımının bazı değişkenler açısından incelenmesi. Kazım Karabekir Eğitim Fakültesi Dergisi, 18, 106124.

Durak Batıgün, A. ve Kılıç, N., (2011). İnternet bağımlılığı: kişilik özellikleri, psikolojik belirtiler, sosyal destek ve ilişkili bazı sosyo-demografik değişkenler arasındaki ilişkiler. Türk Psikoloji Dergisi, 26(67),1-10.

Eldeleklioğlu, J. and Vural, M. (2013). Predictive effects of academic achievement, internet use duration, loneliness and shyness on internet addiction. Hacettepe Üniversitesi Ĕ̈itim Fakültesi Dergisi, 28(1), 141-152

Ellison, N., Steinfield, C. and Lampe, C. (2007). The benefits of Facebook friends: Social capital and college students' use of online social network sites. Journal of Computer Mediated Communication, 12(4), 1143-1168. doi/10.1111/j.1083-6101.2007.00367.x

El-Salameh, E.M. (2011). Irrational beliefs among Jordanian college students and relationships with self- confidence. Asian Social Science, 7(5), 137-144. doi.org/10.5539/ass.v7n5p137

Eraslan-Capan, B. (2015). Interpersonal sensitivity and problematic facebook use in Turkish university students. Anthropologist, 21(3), 395-403.

Eraslan Çapan, B. ve Sarıçalı, M. (2016). Problemli facebook kullanımında sosyal ve duygusal yalnızlığın rolü. İnönü Üniversitesi Eğitim Fakültesi Dergisi, 17(3), 53-66. do1: 10.17679/iuefd.17306122

Erözkan, A. (2005). Üniversite öğrencilerinin kişilerarası duyarlılık ve depresyon düzeylerinin bazı değişkenlere göre incelenmesi. Muğla Üniversitesi SBE Dergisi, 14, 129-155

Field, A. (2005). Discovering statistics using SPSS. London: Sage Publications.

Griffiths, M. D. (2008). Videogame addiction: fact or fiction? İçinde Willoughby \& E. Wood (Eds.), Children's learning in a digital world (s. 85-103). Oxford: Blackwell Publishing. 
Gültekin, B. K. ve Dereboy, İ. F.(2011). Üniversite öğrencilerinde sosyal fobinin yaygınlığ1 ve sosyal fobinin yaşam kalitesi, akademik başarı ve kimlik oluşumu üzerine etkileri, Türk Psikiyatri Dergisi, 22(3), 150-58,

Gürbüz, S. ve Şahin, F. (2016). Sosyal bilimlerde araştırma yöntemleri felsefe-yöntem-analiz. Ankara: Seçkin Yayınevi.

Hamamcı, Z. ve Büyüköztürk, Ş. (2003). İlişkilerle ilgili bilişsel çarpıtmalar ölçeği: ölçeğin geliştirilmesi ve psikometrik özelliklerinin incelenmesi. Çukurova Üniversitesi Eğitim Fakültesi Dergisi, 2(25), 107-111.

Huan, V.S., Ang, R.P. and Chye, S. (2014). Loneliness and shyness in adolescent problematic internet users: The role of social anxiety. Child Youth Care Forum, 43(5), 539-551.

Johnson, H.S., Inderbitzen-Nolan,H.,M. and Anderson, E.R. (2006). The social phobia: Validity and reliability in an adolescent community sample. Psychological Assesment, $18(3), 269-277$

Jose, P. E., Ryan, N., and Pryor, J. (2012). Does social connectedness promote a greater sense of well-being in adolescence over time?. Journal of Research on Adolescence, 22 (2), 235-251. doi:10.1111/j.1532- 7795.2012.00783.x

Kalecik, S. (2016). Emotion regulation, self-control, novelty seeking, depression and social anxiety symptoms in relation to problematic internet and smartphone use. (Yayınlanmamış yüksek lisans tezi). Bahçeşehir Üniversitesi, İstanbul.

Kalkan, N. (2008). Ergenlerde bilişsel yapılar ve sosyal kaygı arasındaki ilişskinin bilişsel davranışçı yaklaşım açısından yorumlanması. (Yayınlanmamış yüksek lisans tezi), Marmara Üniversitesi, İstanbul.

Karakoç, E. ve Taydaş, O. (2013). Bir serbest zaman etkinliği olarak üniversite öğrencilerinin internet kullanımı ile yalnızlık arasındaki. Selçuk Üniversitesi İletişim Fakültesi Akademik Dergisi, 7(4), 33-45.

Karasar, N. (2002). Bilimsel araştırma yöntemi. Ankara: Nobel Yayınevi.

Kelleci, M., Güler, N., Sezer, H., and Gölbaşı, Z. (2009). Relationships gender and psychiatric symptoms with duration of internet use among high school students. Türk Silahlı Kuvvetleri, Koruyucu Hekimlik Bülteni, 8(3), 223-230.

Keser Özcan, N. ve Buzlu, S. (2005). Problemli internet kullanımını belirlemede yardımcı bir araç: internette bilişsel durum ölçeğinin üniversite öğrencilerinde geçerlik ve güvenirliği. Bă̆ımlılık Dergisi, 6(1), 19-26. 
Kurtoğlu, E., (2009.) Lise öğrencilerinde gözlenen saldırganlık düzeylerinin otomatik düşünceler, cinsiyet ve sınıf düzeyi açısından incelenmesi. (Yayınlanmamış yüksek lisans tezi). Ondokuzmayıs Üniversitesi, Samsun.

Madell, D. \& Muncer, S. (2006). Internet communication: An activity that appeals to shy and socially phobic people. CyberPsychology \& Behavior, 9(5), 618-622. do1:10.1089/cpb.2006.9.618

Mai Y, Hu J, Yan Z, Zhen S, Wang S, \& Zhang W. (2012). Structure and function of maladaptive cognitions in pathological internet use among Chinese adolescents. Computers in Human Behavior, 28(6), 2376-2386. doi.org/10.1016/j.chb.2012.07.009

McKenna, K.Y.A., and Bargh, J.A. (2000). Plan 9 from cyberspace: The implications of the internet for personality and social psychology. Personality and Social Psychology Review 4(1), 57-75. do1: 10.1207/S15327957PSPR0401_6

McKenna, K. Y. A., Green, A. S., and Gleason, M. E. J. (2002). Relationship formation on the internet: What's the big attraction? Journal of Social Issues, 58(1), 9-31. doi: $10.1111 / 1540-4560.00246$

Morahan-Martin, J. and Schumacher, P. (2003). Loneliness and social uses of the internet. Computers in Human Behavior, 19(6), 659-671. doi.org/10.1016/S07475632(03)00040-2

Muhtaroğlu, G. (2016). IHKİB Kă̆ıthane mesleki teknik anadolu lisesinde öğrenim gören ergenlerin bilişsel çarpıtma düzeyleri ile stres düzeyleri arasındaki ilişkinin incelenmesi. (Yayınlanmamış yüksek lisans tezi). Nişantaşı Üniversitesi. İstanbul.

Muslu, G. K.. ve Bolışık Z. B, (2009). Çocuk ve gençlerde internet kullanımı, TAF Preventive Medicine Bulletin, , 8(5), 445-450.

Noyan, N.,ve Sertel Berk, Ö., S.,( 2007). Ergenlerde sosyal fobi, içe ve dışa dönük kişilik özellik ve okul başarı durumu. İstanbul Üniversitesi Psikoloji Çalışmaları Dergisi, 27 (1), 31-50.

Liu, C. Y. and Kuo, F. Y. (2007). A study of internet addiction through the lens of the interpersonal theory. Cyber Psychology \& Behavior, 10 (6), 799-804. doi:10.1089/cpb.2007.9951

Peter, J., Valkenburg, P. M., and Schouten, A. P. (2005). Developing a model of adolescent friendship formation on the internet. CyberPsychology \& Behavior, 8(5), 423-430. doi.org/10.1089/cpb.2005.8.423 
Pirinççi, N. L. (2009). Lise öğrencilerinin mükemmeliyetçilik düzeyleri ile kaygı düzeyleri arasındaki ilişkinin incelenmesi, (Yayınlanmamış yüksek lisans tezi). Marmara Üniversitesi, İstanbul.

Ögel, K. (2012). Internet bă̆ımlılı̆̆l: internetin psikolojisini anlamak ve bă̆ımlılıkla başa çıkmak, İstanbul:Türkiye İş Bankası Kültür Yayınları,

Öncü, B. ve Sakarya, A. (2013). Ergen özkıyımlarında bilişsel etmenler ve çarpıtmaların rolü, Psikiyatride Güncel Yaklaşımlar, 5(2), 232-245.

Özolgun Kurt, N. (2014). Meslek lisesi öğrencilerinde problemli internet kullanımı, bilişsel yetenek ve dikkat becerilerinin incelenmesi. (Yayınlanmamış yüksek lisans tezi). Ege Üniversitesi, İzmir.

Öztürk, Ö., Odabaşığlu, G., Eraslan, D., Genç, Y. ve Kalyoncu, Ö.A. (2007). İnternet bağımlılığı: Kliniği ve tedavisi. Bă̆ımlılık Dergisi, 8(1), 36-41.

Santrock, J. W. (2012). Yaşam boyu gelişim: Gelişim psikolojisi (13. baskı). (Çev: G. Yüksel). Ankara: Nobel Yayıncilık.

Sava, F. A. (2009). Maladaptive schemas, irrational beliefs, and their relationship with the five-factor personality model. Journal of Cognitive and Behavioral Psychotherapies, 9(2), 135-147.

Segool N.K. and Carlson J.S. (2008). Efficacy of cognitive-behavioral and pharmacological treatments for children with social anxiety. Depress Anxiety. 25 (7), 620-31. doi:10.1002/da.20410

Siyez, D. M. ve Baş A. U. (2013) İnternet bağımlılığı ve psikososyal faktörler, İçinde M. Kalkan ve C. Kaygusuz (Ed.), Internet bă̆ımlılı̆̆ı: Sorunlar ve çözümler (s. 115-149). Ankara: Anı Yayınc1lık.

Stackert, R. A.and Bursik, K. (2003). Why am I unsatisfied? Adult attachment style, gendered irrational relationship beliefs, and young adult romantic relationship satisfaction. Personality and Individual Differences, 3(8), 1419-1429. doi.org/10.1016/S01918869(02)00124-1

Şahin, M, ve Sarı, S.,V. (2010). Ergenlerde görülen zorbalık eğiliminin bilişsel çarpıtmalar ve fonksiyonel olmayan tutumlarla ilişkisi. Akademik Bakış Dergisi, 20,1-14.

Şahin, S., Özdemir, K. \& Ünsal, A. (2013). Evaluation of the relationship between internet addiction and depression in university students. Medicinski Glasnik, 18(49), 14-27. do1: 10.5937/medgla1349014S 
Şendağ S. and H. F. Odabaşı (2009). Effects of an online problem based learning course on content knowledge acquisition and critical thinking skills. Computers \& Education, 53(1), 132-141. doi.org/10.1016/j.compedu.2009.01.008

Tabachnick, B. G. and Fidell, L. S. (2011). Using multivariate statistics. Boston : Pearson/Allyn \& Bacon.

Taylan, H.H. ve Işı1k, M. (2015). Sakarya'da ortaokul ve lise öğrencilerinde internet bağımlılığı. (Internet addiction among secondary school and high school students in Sakarya). Literature and History of Turkish or Turkic Volume, 10(6), 855-874. doi: 10.7827/TurkishStudies.8286

Temizel, S., (2014). Üniversite öğrencilerinde sosyal kaygıyı yordayan ailesel ve bilişsel faktörler, (Yayınlanmamış yüksek lisans tezi). Ege Üniversitesi, İzmir.

Tuncer, B., ve Voltan-Acar, N. (2006). Kaygı düzeyleri farklı üniversite hazırlık sınıfı öğrencilerinin mükemmeliyetçilik özelliklerinin incelenmesi. Kriz Dergisi,14(2),1-15.

Tunalığlu, Z. (2013). Problematic internet use: a study in Turkey. (Yayınlanmamış yüksek lisans tezi), Boğaziçi Üniversitesi, İstanbul.

Turan, A., F,. (2010). Üniversite öğrencilerinin ilişkilerle ilgili bilişsel çarpıtmalarını yordamada yalnızlık, benlik saygısl, yaş, cinsiyet ve romantik ilişki yaşama durumunun rolü. (Yayınlanmamış yüksek lisans tezi). Anadolu Üniversitesi, Eskişehir.

Türkiye İstatistik Kurumu [TÜİK] (2016). Hanehalkı bilişim teknolojileri kullanımı araştırması. http://www.tuik.gov.tr/PreTablo.do?alt_id=1028 adresinden elde edildi.

Uğur, E. ve Murat, M. (2014). Lise öğrencilerinin kişilerarası ilişkilerle ilgili bilişsel çarpıtmaları ve saldırganlık tepkileri arasındaki ilişkinin incelenmesi. Gaziantep University Journal of Social Sciences, 13 (2), 525-543.

Vatansever-Bulut, Ç. (2016). 12-14 yaş aralığındaki öğrencilerin bilişsel çarpıtmaları ile sosyal fobi belirti düzeyleri arasındaki ilişkinin incelenmesi -Adana ili örneği. (Yayınlanmamış yüksek lisans tezi). Çağ Üniversitesi. Mersin.

Whisman, M.A. and Friedman, M.A. (1998). Interpersonal problem behaviors associated with dysfunctional attitudes. Cognitive Therapy and Research, 22(2), 149-160. doi: 10.1023/A:1018728322555

Yen, J.Y, Ko, C.H, Yen, C.F, Wu, H.Y. and Yang, M.J. (2007). The comorbid psychiatric symptoms of internet addiction: Attention deficit and hyperactivity disorder depression, social phobia, and hostility. Journal of Adolescent Health, 41(1), 93-98. doi.org/10.1016/j.jadohealth.2007.02.002 
Yen, Y. Y., Yen, C. F., Chen, C. S., Wang, P. W., Chang, Y. H. and Ko, C. H. (2012). Social anxiety in online and real-life interaction and their associated factors. CyberPsychology, Behavior, and Social Networking, 15(1),7-12. doi:10.1089/cyber.2011.0015

Yellowlees, P. M., and Marks, S. (2007). Problematic internet use or internet addiction? Computers in Human Behavior, 23(3), 1447-1453. doi: 10.1016/j.chb.2005.05.004.

Young, C. M. Y. and Lo, B. C. Y. (2012). Cognitive appraisal mediating relationship between social anxiety and internet communication in adolescents. Personality and Individual Differences, 52 (1), 78-83. doi.org/10.1016/j.paid.2011.09.001

Young, K. and Rodgers, C., (1998).The relationship between depression and internet addiction. Cyber Psychology and Behavior, 1(1), 25-28. doi.org/10.1089/cpb.1998.1.25

Zorbaz, O. (2013). Lise ögrencilerinin problemli internet kullanımının sosyal kaygı ve akran ilişkileri açısından incelenmesi. (Yayınlanmamış yüksek lisans tezi). Hacettepe Üniversitesi. Ankara.

Zorbaz, O. ve Tuzgöl Dost, M. (2014). Lise öğrencilerinin problemli internet kullanımının cinsiyet, sosyal kaygı ve akran ilişkileri açısından incelenmesi. Hacettepe Üniversitesi Eğitim Fakültesi Dergisi, 29(1), 298-310. 


\section{Extended Abstract}

In recent years, although rapid technological developments make people's life easier; they bring out different kinds of problems. Having troubles in social life, at school or at work because of excessive internet use referred to "Problematic internet use" (Yellowlees \& Marks, 2007). Problematic internet use can be seen at almost all ages, however it becomes a threat for the adolescents particularly aged between 12-18 (Cengizhan, 2005; Şendağ \& Odabaşı, 2007).

There have been abundant of contemporary literature addressing the problematic Internet use in recent years. As the results of these studies, it has been found that problematic internet use is connected with depression, self-esteem, loneliness, timidity, shyness and social support (Ceyhan \& Ceyhan, 2014). At this point, the adolescents' efforts for establishing a relationship on internet networking which they couldn't in their real life are explained by “The Social Compensation Theory" (Peter, Valkenburg \& Schouten 2005). According to this theory individuals who have difficulty in establishing face to face relationship in real life, are trying to compensate their sense of belonging by being a member of a group founded by themselves and self-presentation in cyber world (Ellison, Steinfield \& Lampe, 2007). In addition to that, individuals who have a lower social competence prefer an online communication to face to face communication (Caplan, 2006).

Problematic internet use is investigated with different variables as it has an effect upon different areas of individuals' life. However, there has not been a study in literature examining the relationship between social anxiety and interpersonal cognitive distortions together with problematic internet use. Therefore it is believed that the present study's results might contribute to the development of guidance and psychological counseling services for adolescents to prevent problematic internet use

This research was descriptive study that aims to analyze social anxiety, interpersonal cognitive distortions and gender of problematic internet use of adolescents. In addition the following question was investigated in this study; "Are social anxiety and interpersonal cognitive distortions of adolescents significant predictors of their problematic internet use? “

Participants were consisted of 312 [174 (55\%) females 138 (45\%) males] adolescents. In this study, to determine students' problematic internet use 'Problematic Internet Use ScaleAdolescent' developed by Ceyhan and Ceyhan (2009), to define social anxiety level, 'Social Anxiety Scale for Adolescents' developed by Aydın and Tekinsav-Sütcü (2007) and to define 
interpersonal cognitive distortions' Interpersonal Cognitive Distortions Scale' developed by Hamamc1 and Büyüköztürk, (2003) and to determine other independent variable 'Personal Information Form' developed by researcher were used.

The participants' problematic internet use and social anxiety and interpersonal cognitive distortions were examined by multiple linear regression analyses. Independent sample $t$ test was used to determine whether problematic internet use, social anxiety, interpersonal cognitive distortions of adolescences differentiate in terms of gender.

As a result of the analysis of the data, it was found that problematic internet use was correlated positively with social anxiety, and interpersonal cognitive distortions. According to the results of the regression analysis, the problematic internet use explained $44 \%$ of the variance for social anxiety and interpersonal cognitive distortions $\left(\mathrm{R}=.666, R^{2}=.443\right)$ Social anxiety was the most predictive of problematic internet use. As a result of research it was found that male's problematic internet use and interpersonal cognitive distortions level were higher than females, however there was no significant gender difference in terms of social anxiety

In this study the relation between problematic internet use,social anxiety and interpersonal cognitive distortions of adolescences were investigated. Adolescents can communicate with people they don't know without taking any any risks. Since the adolescents who avoid to have face to face communication and prefer to get socialized in a virtual platform, they can make friends easier via social networks (Eraslan Çapan \& Sarıçalı, 2016). As a result, they compensate their needs such as sharing their social life, being a group member, self-presentation, being approved and liked due to keeping their friendship built on social networks (Eraslan-Capan, 2015; Muslu \& Bolışık, 2009). According to The Social Compensation Theory, the introverted people with social anxiety are tend to compensate their social relationship needs via online relationship established on internet platform. Because of the facilities of internet, these individuals can express themselves easier than they do in real life (McKenna, \& Bargh, 2000; Peter, Valkenburg \& Schouten, 2005). For this reason, the excessive use of internet by adolescents who are trying to compensate their real life social relationship via online pave the way for being a problematic internet user.

Guidance and psychological counseling services at schools can prevent problematic internet use in adolescents by conducting group counseling for adolescents who have social 
Ege Eğitim Dergisi 2017 (18) 2: 887-913

Ergenlerin Problemli İnternet Kullanımında Kişilerarası İlişkilerle İlgili...

anxiety and Interpersonal Cognitive Distortions. In addition to that, activities can be arranged to develop adolescences' social skills by applying psycho-education. Seminars about parenting education and secure Internet use might be developed. 